\title{
Spatial distribution of 0-group eel larvae (Anguilla sp.) in the Sargasso Sea
}

\author{
M. Schoth \& F.-W. Tesch \\ Biologische Anstalt Helgoland (Zentrale); Notkestr. 31, \\ D-2000 Hamburg 52, Federal Republic of Germany
}

\begin{abstract}
Both Atlantic eel species (Anguilla anguilla and A. rostrata) were collected in the Sargasso Sea during the 1979 cruise of the F. R. V. "Anton Dohrn" and R. V. "Friedrich Heincke". A total of 3,097 0-group larvae were caught during 80 hauls using the Isaacs Kidd Midwater Trawl ( 55 hauls) and the 9-fold opening and closing net MOCNESS (25 hauls). 11 hauls of the MOCNESS indicated that the larvae showed a preference for the 150-175 m water depth during daytime and for the $50-75 \mathrm{~m}$ depth during night. The northern distribution limit seems to coincide with the " $18^{\circ} \mathrm{C}$-water" at the sea surface. The Antilla current characterised by higher temperatures and salinities could have been the southern distribution limit. The north-easternmost occurrence of $A$. anguilla was noted at $50^{\circ} \mathrm{W}$ the eastern distribution limit of this species could be farther east. The westernmost station at $69^{\circ} \mathrm{W}$ was positive for both species. $A$. anguilla, therefore, is very likely to occur beyond this area. The easternmost occurrence of $A$. rostrata was noted at $52^{\circ} \mathrm{W}$ though sporadic and with increasing abundance towards the west. At the western end of the network of stations the highest concentration of larvae from both species was recorded. Oceanographic investigations reveal that the distribution of the smaller larvae (size-groups $<7 \mathrm{~mm}$ and $<10 \mathrm{~mm}$ ) almost coincides with the assumed spawning area.
\end{abstract}

\section{INTRODUCTION}

From comprehensive ichthyoplankton surveys at the beginning of this century Schmidt $(1924,1932)$ gained some evidence that the European eel (Anguilla anguilla) does spawn in the Sargasso Sea. Several questions remained to be answered: Among these, the horizontal distribution of the larvae in connection with the hydrographical conditions, the depth preferences and the separation into the species $A$. anguilla and A. rostrata were unsufficiently known.

The cruises of the two German (FRG) research vessels "Anton Dohrn" and "Friedrich Heincke" in 1979 (Tesch, 1982) covered a net of sampling stations which was designed to allow the inclusion of the assumed spawning area of $A$. anguilla. During this expedition newly hatched or several-weeks old eel larvae were caught using different methods. These collections provided new data with respect to the questions mentioned above.

This paper presents the results on the geographical distribution and some results on the vertical preferences of the 0-group larvae. A comparison of the hydrographical conditions and the distribution of the larvae was made on the basis of data collected during the above-mentioned cruise. 


\section{MATERIAL AND METHODS}

Figure 1 shows the network of stations and the route of F. R. V. "Anton Dohrn" during the collection of eel larvae. Included are five stations, not connected by lines, performed by R. V. "Friedrich Heincke". The cruise of F. R. V. "Anton Dohrn" (length $84 \mathrm{~m}$ ) in the Sargasso Sea took place from March 19th to April 17th and April 20th to 27th, 1979. The five stations with larvae collections made by R. V. "Friedrich Heincke" (length $38 \mathrm{~m}$ ) were between March 9th and 14th and on March 26th, 1979. Further details of the cruises (e. g. positions of hauls and stations) and technical details of the ships are given by Tesch (1982) and Tesch et al. (1979).

Two different types of gear were used for the collection of eel larvae. To prove the geographical distribution, one requires a highly effective plankton net because the density of the larvae stock is generally low. As earlier studies on the older leptocephali have shown ${ }_{t}$ one of the most effective gear is the Isaacs Kidd Midwater Trawl (Tesch, 1980). We used a modification of this net, the "Hamburger Planktonnetz" (Bühringer, 1972), with an opening of $6.2 \mathrm{~m}^{2}$, a length of $9 \mathrm{~m}$ and a meshsize of $500 \mu \mathrm{m}$. A smaller version of this IKMT (opening $2.1 \mathrm{~m}^{2}$, length $6 \mathrm{~m}$, meshsize $850 \mu \mathrm{m}$ ) was used on board the R. V. "Friedrich Heincke". Depressor width of both gears was $3 \mathrm{~m}$. The IKMT was towed on all net stations shown in Figure 1. Depth and towing time of the gear were recorded by a time-depth-recorder (Benthos Inc.).

In areas where the IKMT indicated a sufficiently dense stock of young eel larvae, a multiple opening and closing net with 9 nets, each with an opening of $1.4 \mathrm{~m}^{2}$, was towed (MOCNESS, see Wiebe et al., 1976). This gear provided information on the depth occurrence of the larvae by resolving steps of $50 \mathrm{~m}(0-300 \mathrm{~m})$ and steps of $100 \mathrm{~m}$ $(300-500 \mathrm{~m})$. Although the MOCNESS was towed 25 times, 9 hauls had to be discarded because of insufficient functioning. Of the remaining 16 hauls, 11 were positive with respect to 0-group Anguilla larvae. In addition, a smaller opening and closing net with five nets (opening: $0.25 \mathrm{~m}^{2}$ ) was used 55 times without success with respect to leptocephali. Similarly, a neuston net towed 125 times in the Sargasso Sea yielded no Anguilla larvae, although other leptocephalus species were captured.

Using the preliminary results on the depth preferences of the larvae, as proven by MOCNESS hauls, the towing depth was determined at which the IKMT was likely to make its hauls of larvae most effectively both by day and by night. At the beginning of sampling in the Sargasso Sea, the preferred depths were unknown, although from earlier investigations especially on older larvae (Schmidt, 1924; Jespersen, 1942; Tesch, 1980) a diurnal vertical migration by small larvae could be assumed probably not deeper down than $300 \mathrm{~m}$ during daylight and probably around $50 \mathrm{~m}$ during night. For this reason the IKMT was towed obliquely in these depths. After it had been roughly estimated from the MOCNESS hauls which depths had to be considered, the oblique IKMT hauls took place within a smaller range. The density of the larvae at the different geographical positions was calculated on the basis of the time the net was towed in the depths preferred by the larvae. In order to have comparable figures for the different stations, the captured number of larvae were adjusted to 2 hours of towing. The speed of towing was about $2 \mathrm{kn}$ for all types of nets.

The sorting of the larvae was roughly done on board. This was especially necessary in order to find sufficient concentrations of larvae for the use of the MOCNESS and also to evaluate the depth preference of the larvae for further effective IKMT hauls. The rest 
of the ichthyoplankton was preserved in $4 \%$ formalin buffered with borax and sorted in the laboratory. Out of altogether 3,097 0-group larvae $(5.0-30.0 \mathrm{~mm}$ in length; Table 1), 1,043 specimens ( $=33.68 \%$ ) originated from the final sorting in the laboratory. Identification of the larvae took place by myomere counting using the key proposed by Smith (1979) and applied by Schoth (1982). The presence of the two species A. anguilla and $A$. rostrata was ascertained on subsamples by electrophoretic methods (Comparini \& Rodinó, 1980; Comparini \& Schoth, 1982). From the large samples, IKMT No. 33 and 35 with up to 1,000 Anguilla larvae, subsamples of 85 or 228 respectively were taken.

\section{RESULTS}

\section{Vertical distribution}

For the estimation of the vertical distribution we selected eight night and three daylight hauls out of 25 MOCNESS hauls and used the number of eel larvae sorted on board because the sortings were performed relatively carefully as the plankton mass in the MOCNESS was low. The sorting yielded 50 larvae in depths of 50-100 m and 16 in 0-50 $\mathrm{m}$ for the night hauls. 17 larvae in 150-200 $\mathrm{m}$ and 6 larvae in 100-150 $\mathrm{m}$ were the results for the hauls taken during daylight. In depths deeper than $200 \mathrm{~m}$, no 0-group eel larvae were detected (Schoth, 1981). If towing time is considered, these results indicate that during darkness most 0 -group larvae $(78.3 \%$ ) occur between 50 and $100 \mathrm{~m} .21 .7 \%$ of the larvae were captured between 0 and $50 \mathrm{~m}$ i it can be assumed that during our night

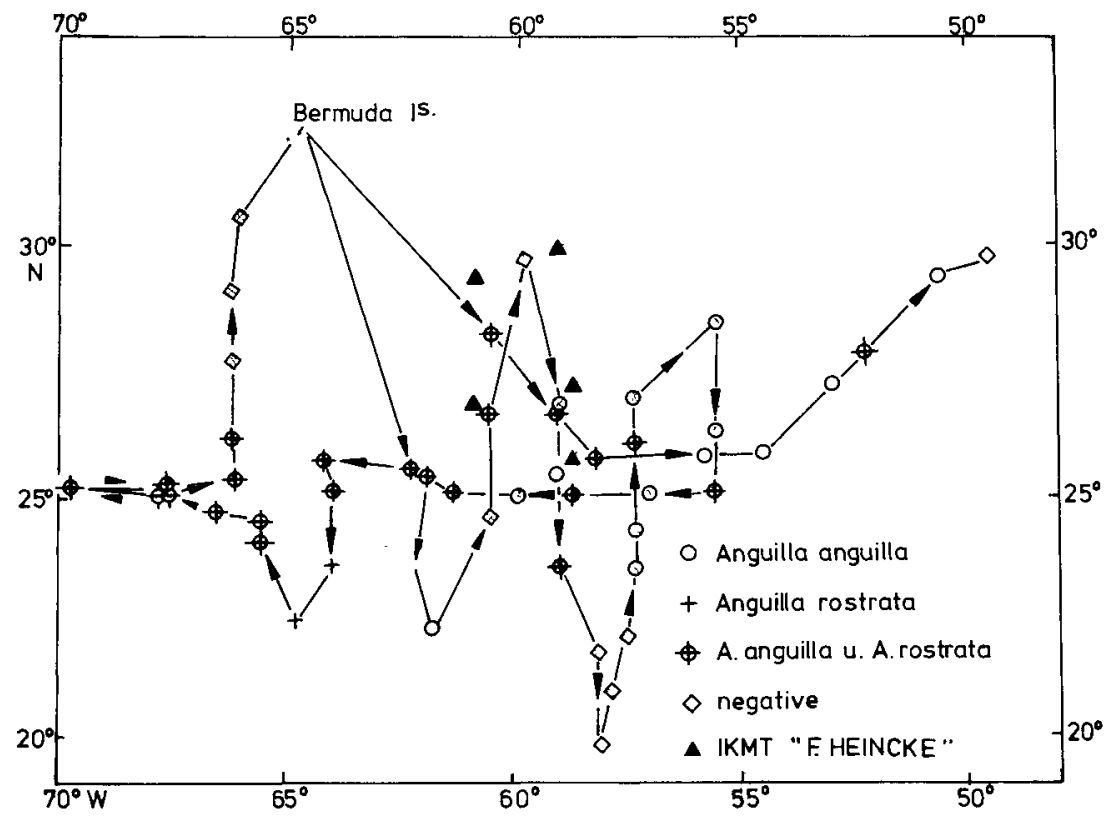

Fig. 1. Course of F. R. V. "Anton Dohrn" with positive and negative IKMT hauls of 0-group ( $<30 \mathrm{~mm}$ ) Anguilla leptocephali; 5 stations not connected with the course were negative IKMT hauls of R. V. "Friedrich Heincke" except at position $27^{\circ} 00^{\prime} \mathrm{N}, 61^{\circ} 00^{\prime} \mathrm{W}$ 


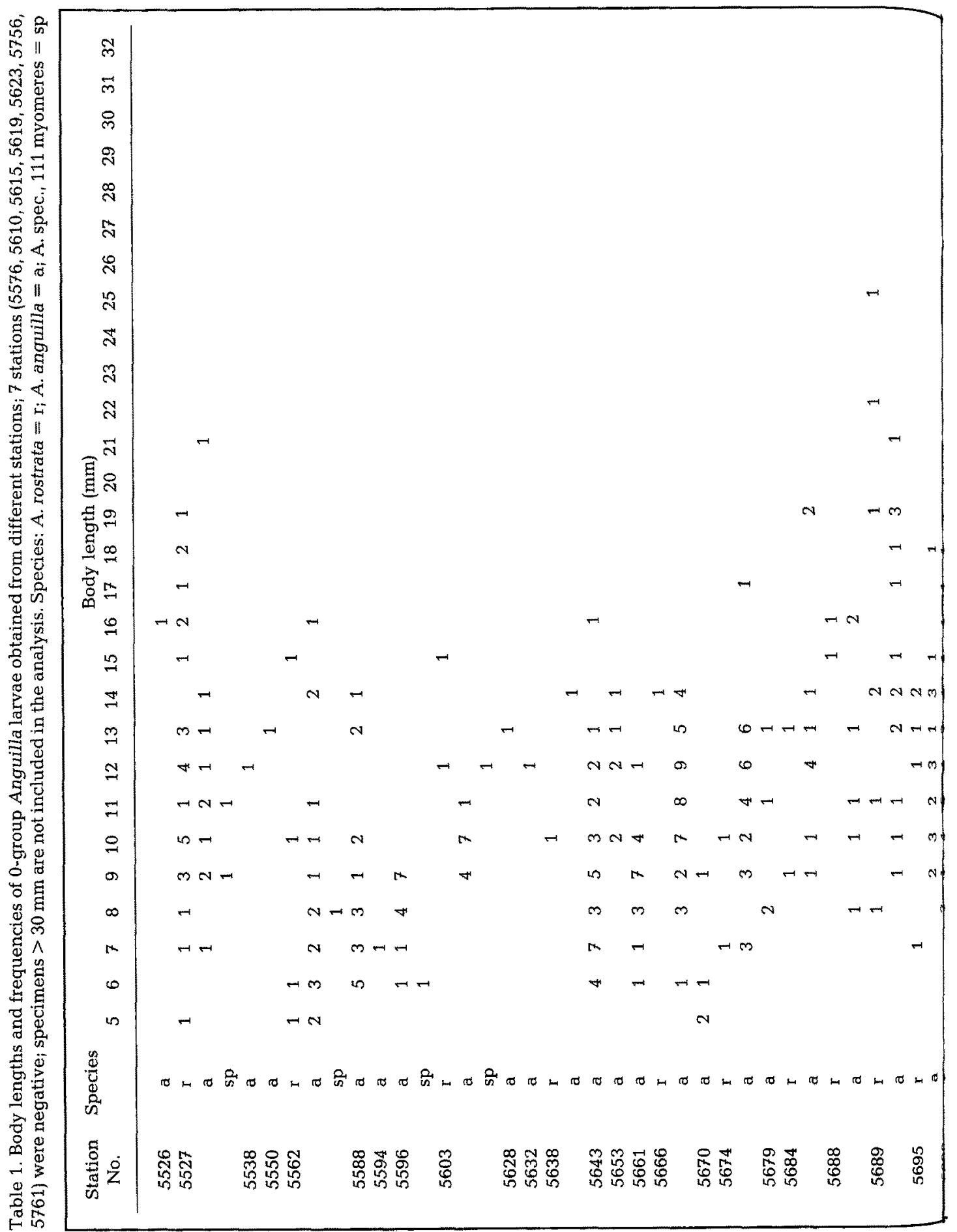




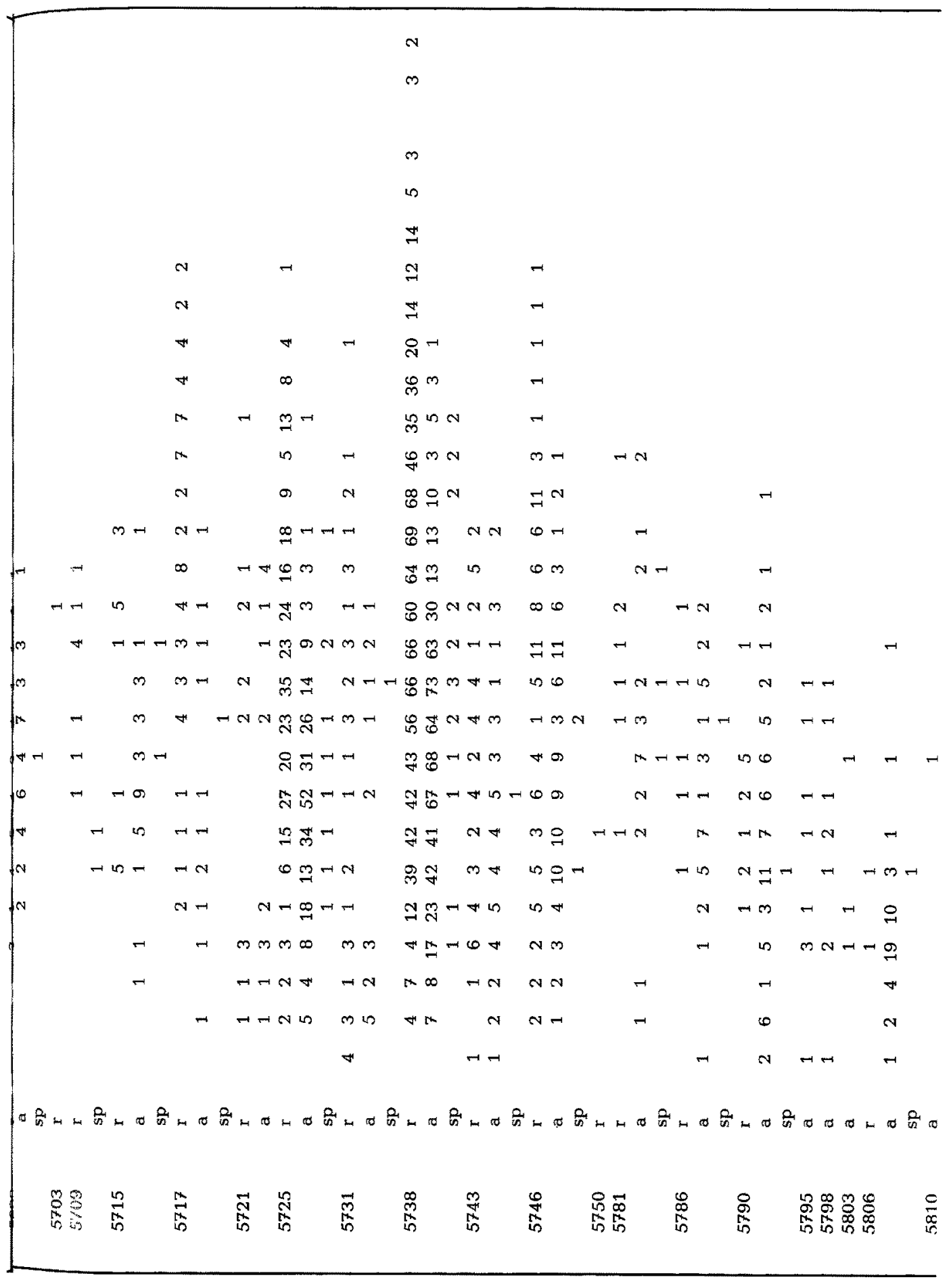


M. Schoth \& F.-W. Tesch

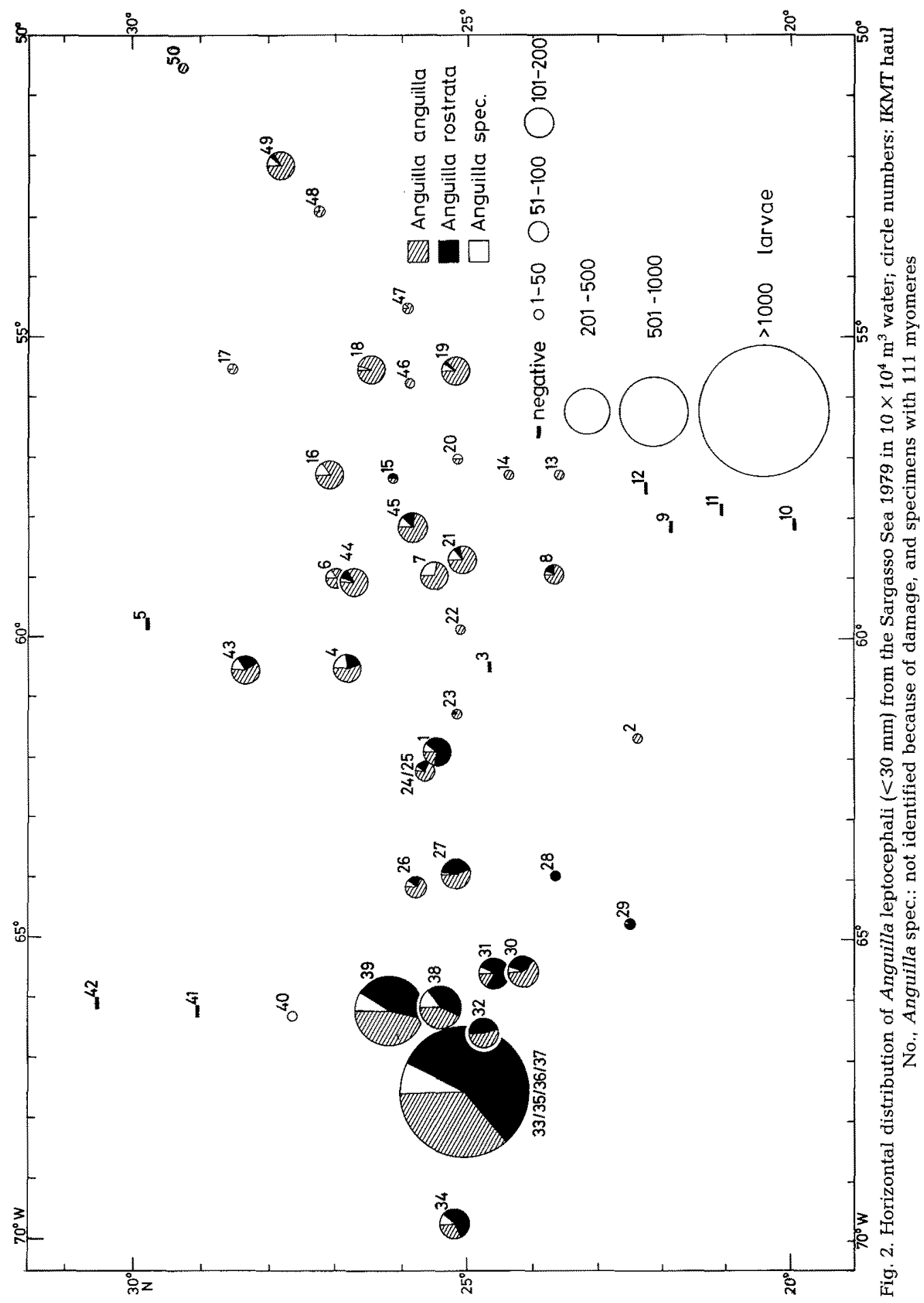


0-group eel larvae in the Sargasso Sea

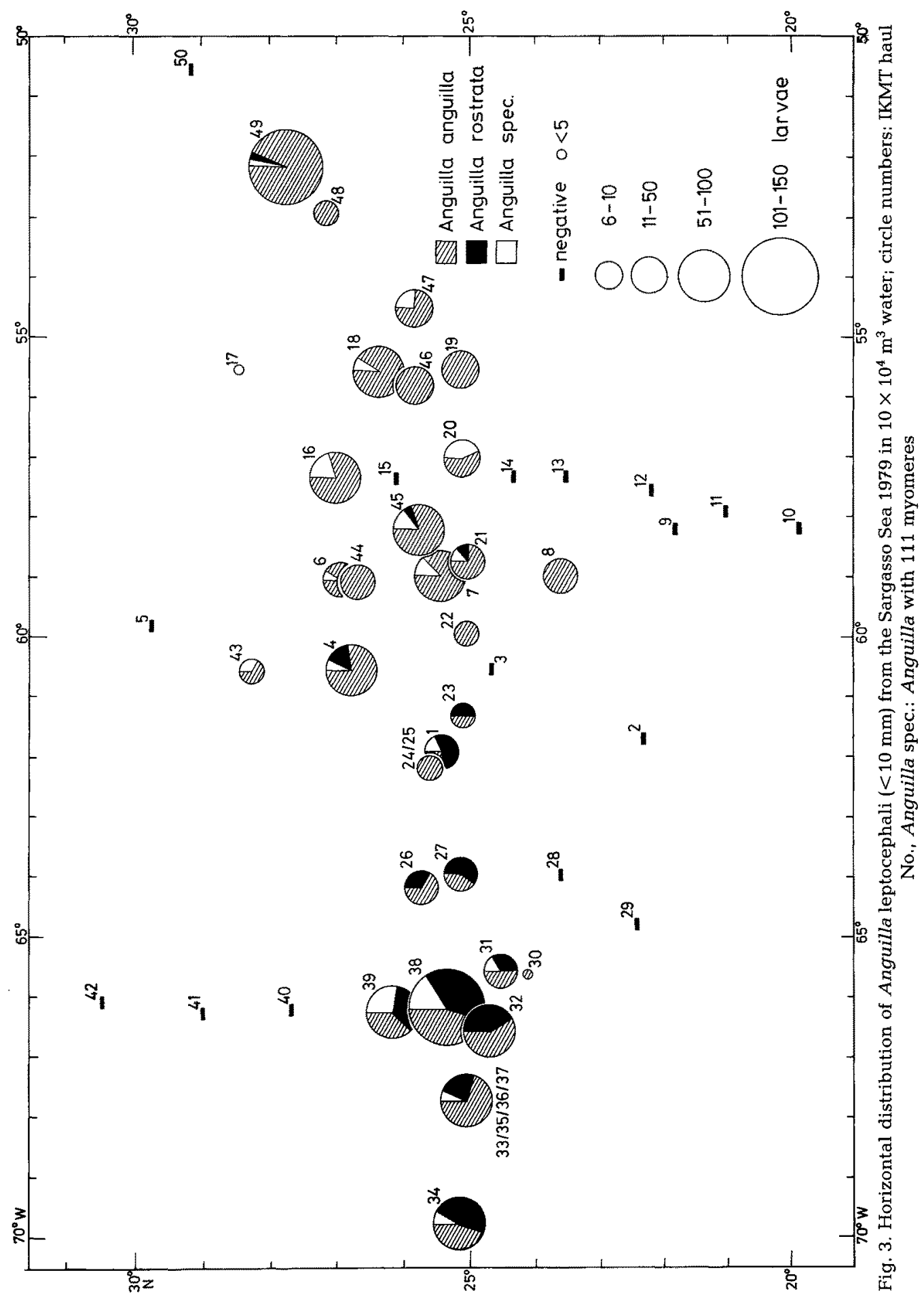


hauls the layer of strongest larvae concentration was between 50 and $75 \mathrm{~m}$. During daylight, $70.4 \%$ were found in depths between 150 and $200 \mathrm{~m}$. The smaller amount $(29.6 \%)$ was sorted out from the $100-150 \mathrm{~m}$ net; it is likely that during daytime the larvae prefer depths between 150 and $175 \mathrm{~m}$. We therefore assume that between daylight and darkness a vertical migration of about $100 \mathrm{~m}$ takes place.

\section{Horizontal distribution}

Figure 1 presents the geographical distribution of 0-group larvae of $A$. anguilla and $A$. rostrata as revealed by positive and negative hauls including the five stations with mostly negative results gained by R. V. "Friedrich Heincke". The negative hauls of F. R. V. "Anton Dohrn" were in the south-east, in the north and in the north-east. All other stations farther to the north-east also gave negative hauls and are not included in this graph. The northeastern limitation of occurrence, about $50^{\circ} \mathrm{W}$, is not necessarily the eastern boundary. This could only have been proven if more central eastern hauls had been made. Similarly, the four southeastern stations with negative results are not proof of the southernmost occurrence, since all southernmost stations gave positive results. In the west, also, no distribution limits were found.

A. anguilla was present in the whole area except two stations in the south-west. A. rostrata did not occur in most of the hauls east of $57^{\circ} \mathrm{W}$ but was still present $52^{\circ} \mathrm{W}$ (two specimens).

The geographical distribution of the Anguilla larvae is shown graphically in Figures 2 to 4 . The density calculations were made on the basis of the depth occurrence shown by the MOCNESS hauls; e.g. if the total number of Anguilla larvae caught by IKMT night haul No. 6 (Station 5588) is 20 the number of larvae obtained in $2 \mathrm{~h}$ fishing time $(1 \mathrm{~h}$ in $0-50 \mathrm{~m} ; 1 \mathrm{~h}$ in $50-100 \mathrm{~m}$ ) would be 36.4 corresponding to a towing time of $0.67 \mathrm{~h}$ in $0-50 \mathrm{~m}$, or $0.52 \mathrm{~h}$ in $50-100 \mathrm{~m}$. In addition, the number of $A$. anguilla, A. rostrata and Anguilla spec. was calculated using these figures and the quantity in $10 \times 10^{4} \mathrm{~m}^{3}$ of water (filtered volume $=$ speed $\times$ net opening $\times$ time of towing). From these Figures it is still more obvious than from Figure 1 that the abundance of A. rostrata decreases from west to east. In regard to the smaller larvae of $A$. anguilla (Figs 3 and 4 ) they seem to occur in the central latitudes in similar quantities over the whole of the east-west range. In the western region, however, a peak of abundance of both species (Figs 2 to 4 ) is visible. These strong concentrations of larvae at the west end of the investigated area were found within a patch of about 50 nautical miles. Concerning the small larvae ( $<7 \mathrm{~mm}$ ) of $A$. rostrata, $58^{\circ} \mathrm{W}$ was the eastern limit although $2 A$. rostrata specimens smaller than $10 \mathrm{~mm}$ still occurred $52^{\circ} \mathrm{W}$.

\section{DISCUSSION}

At the beginning of the trawling during the 1979 cruise in the Sargasso Sea, it was quite uncertain at which depth during day and night the eel larvae occurred. The first qualitative proofs by IKMT on the occurrence of larvae are for this reason not very reliable. This concerns especially the collections made by R. V. "Friedrich Heincke". During the greatest part of the hauls the net fished in a depth of about $25 \mathrm{~m}$, which is probably out of the depth range of the small larvae. Probably the time of towing was too short in the depth preferred by the larvae. In addition, the greatest part of the hauls took 
0-group eel larvae in the Sargasso Sea

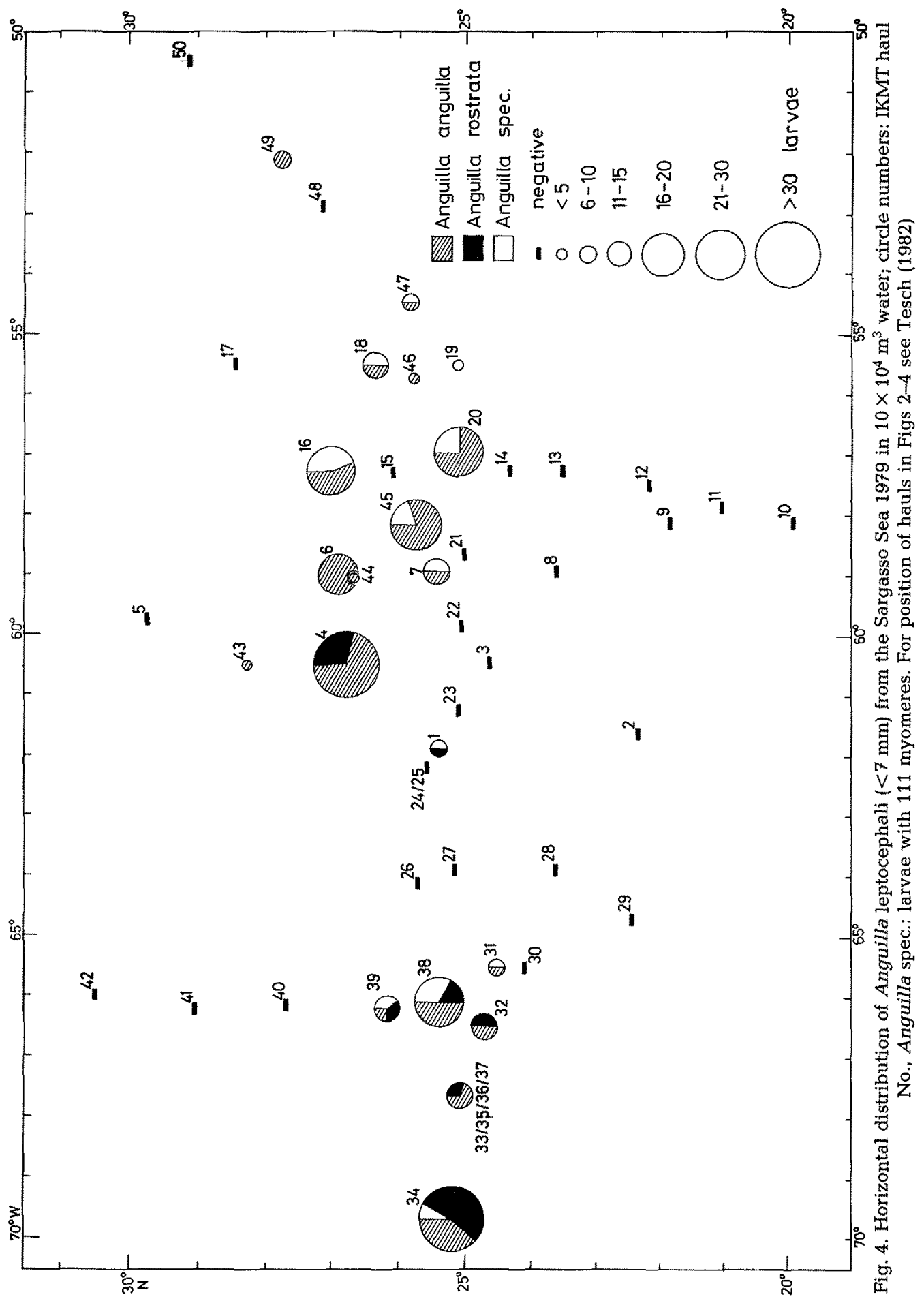


place very early in the year, when spawning of $A$. anguilla was probably only just beginning. Moreover, the mesh size of the R. V. "Friedrich Heincke" IKMT was too big $(850 \mu \mathrm{m})$ to retain the smallest larvae. The only result we can therefore offer from the five hauls is that spawning of $A$. anguilla was, as Schmidt (1924) suggested, at the start of the spawning season. In addition, the first and some other hauls of F. R. V. "Anton Dohrn" were not towed long enough at the correct depth to have proof of the occurrence or even a rough idea of the density of the larvae stock. The picture given for some stations may also be incorrect, as towings of the IKMT and the density calculations are based on too small a number of MOCNESS hauls. Probably the depth preference of the larvae is more differentiated than is evident from our hauls; it may change from noon to afternoon, from afternoon to dawn and from the first hours of darkness to midnight. The depth preference of the smaller larvae may also differ from that of the bigger larvae.

The negative IKMT hauls Nos 9 and 11 may be doubtful although the nearby hauls Nos 10 and 12 were relatively correct as far as depth was concerned. We think that here the Antilla Current does prevent occurrence of larvae. The temperature at $100 \mathrm{~m}$ increases within a short range from 23.5 to $>25^{\circ} \mathrm{C}$. There is also an increase in salinity (37.0\%) compared to that of the central Sargasso Sea (36.8\%) (Wegner, 1982). In the north, the negative haul No. 42 may be doubtful. Nos 41 and 5 are also negative but these seem to be correct. Very likely, spawning and larvae occurrence is limited by the northern " $18^{\circ} \mathrm{C}$-water" which reaches the surface here in winter (Istoshin, 1961; Worthington, 1959, 1976). In the northern Sargasso Sea in the months from February to March this water layer extends from the surface to a depth of $200-400 \mathrm{~m}$. Farther south the " $18^{\circ} \mathrm{C}$-water" begins in a depth of about $300 \mathrm{~m}$, extending downward but with decreasing depth and its southern limit is about $20^{\circ} \mathrm{N}$ which was similar during the 1979 expedition (Wegner, 1982).

There is no doubt that the occurrence of larvae smaller than $7 \mathrm{~mm}$ and even that of larger larvae is congruent with the spawning area of the adults. From the breeding experiments of Yamamoto \& Yamauchi (1974) and Yamauchi et al. (1976) Anguilla larvae having a length of $7 \mathrm{~mm}$ must be 7 to 14 days old. Geostrophical computations on the hydrography in the central Sargasso Sea by Wegner (1982) resulted in a current of $1-2 \mathrm{~cm} / \mathrm{sec}$ in a great part of the area in question, which is too weak to carry the $7 \mathrm{~mm}$ larvae farther than $13 \mathrm{~nm}$ within two weeks. Velocity is much greater farther south in the Antilla Current $(15 \mathrm{~cm} / \mathrm{sec})$ and in the area of $25^{\circ} \mathrm{N}$, for example, not far from the stations where we found mass concentrations of larvae. The hydrographic measurements suggest the existence of at least two gyres in this latitude which may have a current speed of $<17 \mathrm{~cm} \cdot \mathrm{sec}^{-1}$ at a maximum. The question is, whether the mass occurrence of larvae in this area results from side currents of these gyres. Another explanation for the higher larvae occurrence in this area may be the production of a patch by a strong concentration of spawners.

A comparison with earlier results on $A$. anguilla (Fig. 5) shows that we are essentially in accordance with Schmidt $(1924,1932)$. This is especially true where latitude is concerned. It is striking that the area of the $7 \mathrm{~mm}$ long $A$. anguilla, the "Schmidt's Cigar", is comparatively small (Boëtius, personal communication). We found a much greater extention to the west. Also to the east, our area of geographical distribution seems to indicate a wider range. This is remarkable because our collection is the result of only one cruise whereas Schmidt's (1932) material is based on at least four cruises. These 


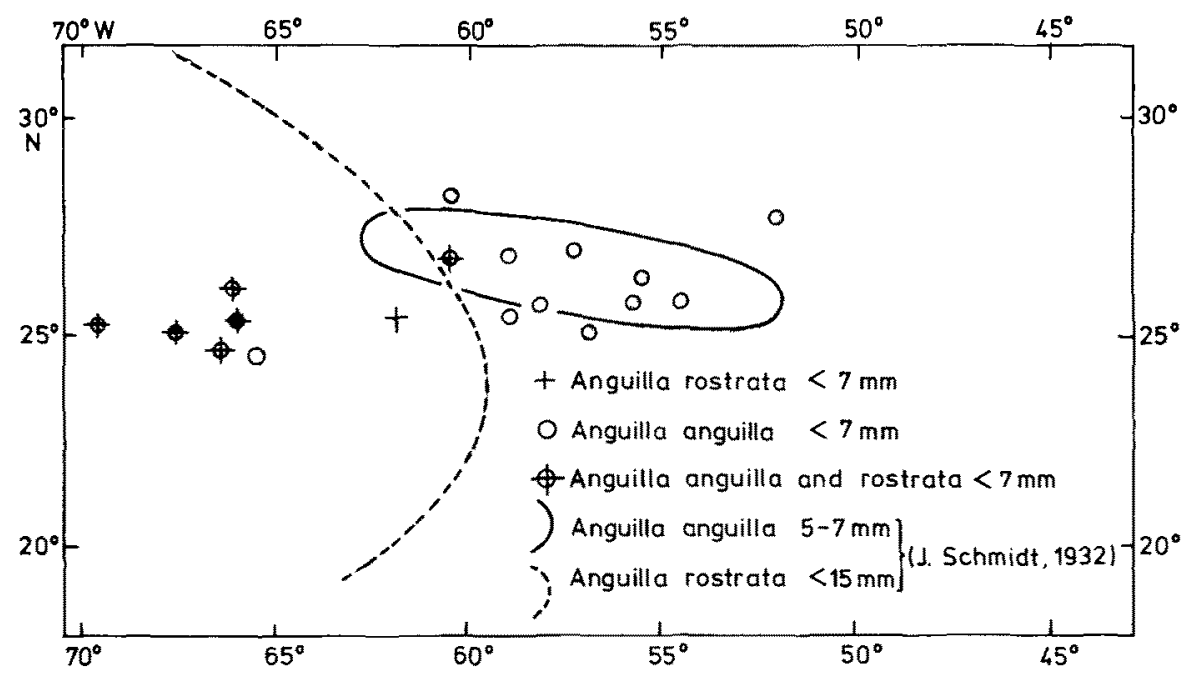

Fig. 5. Comparison of the 1979 eel larvae collections with the results obtained by Schmidt (1932)

cruises should have provided material exhibiting a much broader area of occurence of $7 \mathrm{~mm}$ larvae because hydrographic conditions may have varied between years. Probably the IKMT was more effective in proving geographical distribution than Schmidt's $2 \mathrm{~m}$ ring trawl. On the margin of the spawning area where fewer larvae occur, Schmidt's hauls therefore could have been negative where we might have had positive hauls. An overlapping of the spawning areas of the two species from Schmidt's (1932) results was likely. We found a considerable overlapping of the $7 \mathrm{~mm}$ larvae, whereas the $10 \mathrm{~mm}$ larvae area of $A$. rostrata was congruent for the greatest part with the area covered by A. anguilla; the northern boundaries were probably exactly the same for both species. In the south-west and west further investigations are necessary. In regard to A. rostrata its increasing density in the west suggests a much more extended spawning area in this direction; we are informed (Smith, personal communication; Kleckner \& McCleave, 1982) that even in the Strait of Yucatan, A. rostrata, 11-17 $\mathrm{mm}$ in length, could be collected which makes spawning in the Caribic likely.

Acknowledgements. These results are part of a thesis (Diplomarbeit im Fachbereich Biologie der Universität Hamburg, Institut für Hydrobiologie und Fischereiwissenschaft). We wish to thank Drs. I. and J. Boëtius (Copenhagen), Prof, Dr. Schnack, Dr. D. G. Smith (Galveston, Texas) for useful suggestions and assistance, Drs. H.-C. John and G. Peters for managing sampling equipment and assistance on board and C. Berger for her help in preparing the English text.

\section{LITERATURE CITED}

Bühringer, H., 1972. "Hamburger Planktonnetz", ein neues Planktonmassenfanggerät erfolgreich eingesetzt. - Infn Fischw. 19, 183-186.

Comparini, A. \& Rodinó, E., 1980. Electrophoretic evidence for two species of Anguilla leptocephali in the Sargasso Sea. - Nature, Lond., 287, 435-437.

Comparini, A. \& Schoth, M., 1982. Comparison of electrophoretic and meristic characters of 0-group eel larvae from the Sargasso Sea. - Helgoländer Meeresunters. 35, 289-299. 
Istoshin, Yu. V., 1961. Formative area of "eighteen degree water" in the Sargasso Sea. Okeanologiya 1,600-607.

Jespersen, P., 1942. Indo-Pacific leptocephalids of the genus Anguilla. - Dana Rep. 22, 1-128.

Kleckner, R. C. \& McCleave, J. D., 1982. Entry of migrating American eel leptocephali into the Gulf stream system. - Helgoländer Meeresunters. 35, 329-339.

Schmidt, J., 1925. The breeding places of the eel. - Rep. Smithson. Instn 1924, 279-316.

Schmidt, J., 1932. Danish eel investigations during 25 years (1905-1930). Nordisk Forl. Kobenhavn, $16 \mathrm{pp}$.

Schoth, M., 1981. Die Verteilung der frühen Leptocephalus-Stadien des atlantischen Aales der deutschen Sargassomeer-Expedition 1979. - Universität Hamburg, Inst. f. Hydrobiol. u. Fischereiwiss. (unpubl.).

Schoth, M., 1982. Taxonomic studies on the 0-group eel larvae (Anguilla sp.) caught in the Sargasso Sea in 1979. - Helgoländer Meeresunters. 35, 279-287.

Smith, D. G., 1979. Guide to the leptocephali (Elopiformes, Anguilliformes, and Notacanthiformes). - NOAA tech. Rep. NMFS Circ. 424, 1-39.

Tesch, F.-W., Kracht, R., Schoth, M., Smith, D. G. \& Wegner, G., 1979. Report on the eel expedition of F.R.V. "Anton Dohrn" and R.V. "Friedrich Heincke" to the Sargasso Sea 1979. - C. M./ICES, M6.

Tesch, F.-W., 1980. Occurrence of eel, Anguilla anguilla, larvae west of the European continental shelf, 1971-1977. - Envir. Biol. Fish. 5, 185-190.

Tesch, F.-W., 1982. The Sargasso Sea Eel Expedition 1979. - Helgoländer Meeresunters. 35, 263-277.

Wegner, G., 1982. Main hydrographic features of the Sargasso Sea in Spring 1979. - Helgoländer Meeresunters. 35, 385-400.

Wiebe, P. H., Burt, K. H., Boyd, S. H. \& Morton, A. W., 1976. A multiple opening/closing net and environmental sensing system for sampling zooplankton. - J. mar. Res., 34, 313-326.

Worthington, L. V., 1959. The $\mathbf{1 8}^{\circ}$ water in the Sargasso Sea. - Deep-Sea. Res. 5, $297-305$.

Worthington, L. V., 1976. On the North Atlantic circulation - Johns Hopkins oceanogr. Stud. 6 , $1-110$.

Yamamoto, K. \& Yamauchi, K., 1974. Sexual maturation of Japanese eel and production of eel larvae in the aquarium. - Nature, Lond. 251, 220-222.

Yamauchi, K., Nakamura, M., Takahashi, H. \& Takano, K., 1976. Cultivation of larvae of Japanese eel. - Nature, Lond. $263,412$. 